\title{
Effects of extending rotation period on plant species diversity in Larix kaempferi plantations in central Japan
}

\author{
Takuo NAGAIKE*, Atsuko HAYASHI \\ Yamanashi Forest Research Institute, Masuho, Yamanashi 400-0502, Japan
}

(Received 11 December 2002; accepted 14 April 2003)

\begin{abstract}
We compared the plant species diversity of forest-floor vegetation in long-rotation Larix kaempferi plantations with standardrotation plantations and abandoned coppice forest in central Japan. Species diversity and richness did not differ between the standard- and longrotation plantations. However, the composition of tall-tree species, of different seed-dispersal types, in long-rotation plantations differed from that in standard-rotation plantations, but was similar to that in abandoned coppice forest. These results indicate that, in particular, long-rotation plantations contained more tall-tree species with animal-dispersed seeds, which in turn suggests that long-rotation plantations may be better for colonization of tall-tree species with this type of seed dispersal. The relatively long period since management in long-rotation plantations may play a significant role in the growth, reproduction, and seedfall of naturally regenerated tall-tree species with animal-dispersed seeds. Therefore, long-rotation plantations may maintain and restore species composition via recovering ecological function.
\end{abstract}

forest ecosystem management / seed dispersal / species classification / life form

Résumé - Effets de l'allongement de la période de rotation des plantations de Larix kaempferi au centre du Japon sur la diversité en espèces végétales. Nous avons comparé la diversité en espèces végétales du sous bois entre des plantations de Larix kaempferi menées en rotations longues par rapport à des rotations classiques courtes ou des taillis abandonnés. La diversité et la richesse en espèces végétales ne diffèrent pas entre les plantations classiques et les plantations à longue rotation. Cependant, la diversité de la strate arborée, avec des stratégies de dispersion des graines différentes, diffère entre les plantations à longue durée par rapport aux plantations classiques mais est semblable aux taillis abandonnés. Les résultats indiquent en particulier que les plantations avec de longues rotations contiennent plus d'espèces arborées avec une stratégie de dissémination des graines par zoochorie ce qui suggère également que ce type de plantation longue soit favorable aux arbres avec ce type de dissémination. La longue période après la dernière intervention en forêt dans les plantations à longue rotation semble donc jouer un rôle important dans la croissance, la reproduction et la dispersion des graines par zoochorie pour les arbres se régénérant naturellement. Par conséquent, les plantations à longue rotation pourraient maintenir et restaurer la composition en espèces végétales par rétablissement de la fonction écologique.

gestion des écosystèmes forestiers / stratégie de dispersion des graines / classification des espèces / type biologique

\section{INTRODUCTION}

Biological diversity is considered important in plantation ecosystems, as forest management increasingly focuses on being ecologically sustainable and plantations take on multiple functions, such as habitat for wildlife and plants, rather than the single function of timber production [12, 15, 29, 30]. Studies of plant species diversity in plantations have recently increased in number (e.g., [7, 25, 31]). However, data are still lacking on which to base the management of both biological conservation and timber production in plantations. Some researchers have recommended long-rotation plantations as one source of such data $[12,19,36,37,41]$. Long-rotation plantations have been found to maintain and restore species diversity and stand struc- ture, important factors for wildlife and plant habitat, to a greater extent than standard-rotation plantations [7, 14, 19, 27]. Peterken et al. [36] showed that the stand structure of long-rotation plantations could provide 'old growth' habitats. Full investigation of how extending the length of rotation affects the biological diversity of plantations is imperative, because such empirical data are, to date, limited.

Many studies have used indices of species diversity (e.g., Shannon diversity $\left[H^{\prime}\right]$, equitability $\left[J^{\prime}\right]$ ) and species richness to evaluate plant species diversity in forests (e.g., [9, 47]). However, these indices do not directly represent the specific ecological characteristics of the community [5, 24, 35]. Therefore, species with ecological characteristics that are sensitive to specific management regimes need to be identified $[31,43]$.

\footnotetext{
* Corresponding author: nagaike@ @op21.odn.ne.jp
} 


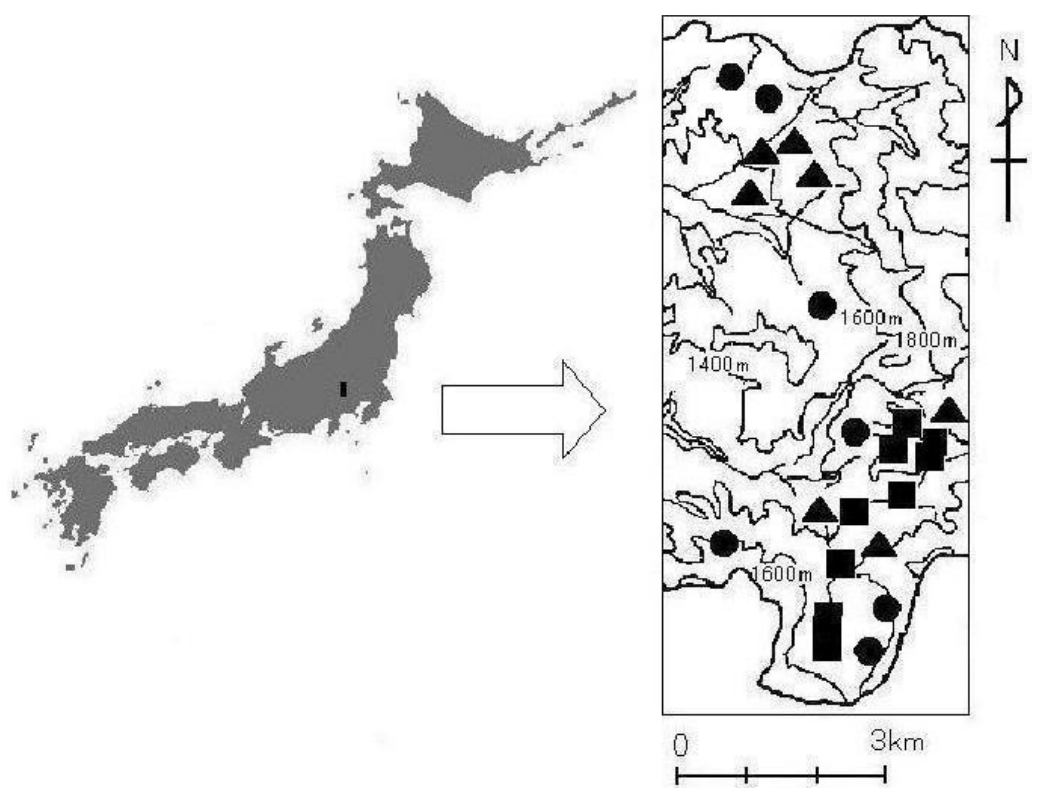

Figure 1. Location of the study area and the study plots; - OLD (long-rotation plantations, $n=7$ ), ש: MID (standard-rotation plantations, $n=10$ ), $\Delta$ : SEC (abandoned coppice forests, $n=7$ ).
Nagaike [31] showed that the species composition, which is characterized by differences in life form and seed dispersal types, clearly differed between broad-leaved secondary forest and Larix kaempferi plantations. Type of life form and seed dispersal are thought to be ecologically important traits in response to disturbance $[4,11,26]$. In an Appalachian hardwood forest, the herbaceous component of the herb layer was significantly greater in young clear-cut stands than in mature stands, whereas the woody component of the herb layer was significantly greater in mature stands [9]. Pinard et al. [39] also suggested that forest management decisions should consider the type of plant-animal interaction in relation to seed dispersal. Since such traits are probably good indicators of the effects of the forest management systems used, we focused not only on diversity indices but also on the ecological characteristics of the species found in each type of forest.

Comparing plant species diversity among the forest types caused by different management regimes in a forested landscape is a useful way to understand how management affects such diversity (e.g., [3, 17, 31]). Thus, investigation of plant species diversity in long-rotation plantations requires comparison with standard-rotation plantations. Roberts and Zhu [42] compared a plantation that had been clear-cut and subsequently replanted with an abandoned coppice forest that had been clearcut and allowed to regenerate naturally. They showed that plant species diversity was much more severely affected in the plantation. Thus, comparison of plantations with abandoned coppice forest should help determine whether long rotation can mitigate the effects of standard rotation in plantations.

We evaluated the plant species diversity of forest-floor vegetation in long-rotation L. kaempferi plantations, as compared with that of standard-rotation plantations and abandoned coppice forest, in central Japan. Our specific objectives were to determine the effects of stand age and different management practices on species composition in relation to species' ecolo- gical characteristics (i.e., life form type), which are thought to reflect the intensity and frequency of management of an area, and to determine the link between such effects and types of seed dispersal.

\section{STUDY SITE AND METHODS}

This study was conducted in a forested area of approximately 900 ha, comprised mainly of L. kaempferi plantations and broad-leaved abandoned coppice forests (Fig. 1, Sutama, Yamanashi Prefecture, central Japan [1200-1600 m a.s.1.; $\left.35^{\circ} \mathrm{N}, 138^{\circ} \mathrm{E}\right]$ ). About $53 \%$ of the study area was covered by plantation (50\% standard rotation and $3 \%$ long rotation) and $29 \%$ was covered by abandoned coppice forests. The area receives approximately $1120 \mathrm{~mm}$ mean annual precipitation; the mean annual temperature is $9.9^{\circ} \mathrm{C}$, and snow cover in winter is less than $1 \mathrm{~m}$. These climatic data indicate that the study site is located in the low-snow, cool-temperate zone of Japan. Dry inland areas in Japan (similar to the study site), typified by light snow cover and cold winters, are the usual plantation sites for Larix kaempferi, a tall deciduous conifer. The natural vegetation of this area is thought to have been mixed forest, dominated mainly by Quercus crispula, Fagus japonica, and Abies homolepis. Beginning in the 1940s, the primary and secondary broad-leaved deciduous forests in the area were drastically overcut, and L. kaempferi plantations were established. In addition to these plantations, primary and old growth forests were replaced by coppice forests (subsequently abandoned), characterized by $Q$. crispula, $Q$. serrata, and Betula platyphylla.

In 1999 and 2000, we established 24 study plots $(10 \times 100 \mathrm{~m}$ each; 2.4 ha total area) in three types of forest (L. kaempferi plantations with stands of two different ages and abandoned coppice forests). The plantation study plots were classified by stand age: 34 to 43 years (MID; $n=10$ ), and 57 to 78 years (OLD; $n=7$ ). The MID plots had not been thinned for at least 5 years, and the OLD plots for about 30 years. Because the standard rotation of L. kaempferi plantations in this area is 40 years, the OLD plots were considered long-rotation plantations. In all of the plantations sampled in this study, normal management practices had been carried out (i.e., weeding, salvage cutting, and thinning) at scheduled times (e.g., the 37-year-old plot had been weeded twice, thinned once, and subjected to salvage cutting four times). The 
Table I. Parameters of stand structure and light environment for the three forest types. Mean diameter at breast height (DBH), basal area (BA), and relative photosynthetic photon flux density (RPPFD) were compared using the Kruskal-Wallis test, and the relative dominance of planted Larix was compared using the Mann-Whitney $U$ test. When a significant difference was calculated by the Kruskal-Wallis test, each pair of types was analyzed using a Mann-Whitney $U$ test with adjusted Bonferroni multiple comparisons. Different letters indicate significant differences by adjusted Bonferroni multiple comparisons among forest types at $P<0.017$.

\begin{tabular}{|c|c|c|c|c|c|c|c|}
\hline & \multicolumn{2}{|c|}{$\operatorname{MID}(n=10)$} & \multicolumn{2}{|c|}{ OLD $(n=7)$} & \multicolumn{2}{|c|}{$\operatorname{SEC}(n=7)$} & \\
\hline & Mean & S.D. & Mean & S.D. & Mean & S.D. & \\
\hline Mean DBH $(\mathrm{cm})$ & 15.6 & 3.5 & 12.7 & 1.9 & 12.7 & 1.3 & 0.107 \\
\hline $\mathrm{BA}\left(\mathrm{m}^{2} / \mathrm{ha}\right)$ & 31.7 & 4.8 & 34.7 & 6.7 & 38.5 & 15.4 & 0.470 \\
\hline Relative dominance of planted Larix (\%) & 84.3 & 12.6 & 69.6 & 16.7 & - & - & 0.043 \\
\hline RPPFD (\%) & 11.6 & $10.6 \mathrm{a}$ & 3.2 & $1.3 \mathrm{~b}$ & 19.2 & $10.1 \mathrm{a}$ & 0.002 \\
\hline
\end{tabular}

MID: standard-rotation plantations, OLD: long-rotation plantations, SEC: abandoned coppice forests, S.D.: standard deviation.

age of the abandoned coppice forest plots (SEC; $n=7)$ was approximated at 50 years using tree ring analysis of cores. The SEC plots had not been recently managed. The belt-shaped plots were designed to sample the topographical variation of each forest and thus minimize variation in natural conditions among the forest types $[8,16,31,32$, 33]. All plots were located at the center of each forest to avoid any edge effects caused by differences in neighboring forest.

All study plots were divided into $5 \times 5-\mathrm{m}$ subplots, and a $1 \times 1-\mathrm{m}$ quadrat was established in each subplot to study forest-floor vegetation. Thus, we had 40 subplots and quadrats in each plot, 960 subplots and quadrats in total. In every subplot, we identified all living trees greater than $3 \mathrm{~cm}$ in diameter at breast height $(\mathrm{DBH})$ and measured their girth at breast height. Their DBH was calculated by their girth. We also recorded the species of all vascular plant species less than $2 \mathrm{~m}$ high in each $1 \times 1-\mathrm{m}$ quadrat to determine the presence and absence of species in each quadrat. Species diversity and richness in each plot were quantified using the Shannon diversity index $\left(H^{\prime}\right)$, equitability index $\left(J^{\prime},[38]\right)$, and number of species per unit area. The $H^{\prime}$ and $J^{\prime}$ values were calculated from the frequency (1 to 40) of occurrence of each species in each plot. The $H^{\prime}$ and $J^{\prime}$ indices were given using the following formulas:

$$
\begin{aligned}
H^{\prime} & =\sum_{i=1}^{m} p i \ln p i, \\
J^{\prime} & =H^{\prime} / \ln m,
\end{aligned}
$$

where $p i$ is the relative frequency of occurrence of each species in each plot, and $m$ is the number of species occurring in each plot.

We also determined the association between species and forest type. Species found to be unique to, or biased toward, a particular type of forest were then used in the analyses. To characterize the properties of species found in each forest type, we analyzed the species with a bias toward a particular type (by chi-square and Fisher's exact tests) in addition to the species that occurred in one type only. For example, species described as tending to inhabit OLD plots occurred significantly more frequently in OLD than in MID or SEC plots or occurred in only OLD plots.

We focused on species type and seed-dispersal type as ecological characteristics. Species were classified on the basis of life form as tall trees, sub-tall trees, shrubs, vines, perennials, winter annuals, annuals, or ferns. The four seed-dispersal types were based on the principal agent of dispersal: birds, small animals, wind, or gravity. For species with several modes of dispersal, we classified the dispersal agent of acorn-bearing species as small animals and that of fleshy-fruit species as birds. We used illustrated guidebooks to identify species type and dispersal type [20-23, 34].
To quantify the light environment in the study plots, we used a digital camera with a fish-eye converter (Nikon Cool Pix 950) to take hemispherical photographs of the canopy from $1 \mathrm{~m}$ above the ground every $5 \mathrm{~m}$ along the center line of each $10 \times 100-\mathrm{m}$ plot $(n=480$ in total). We used the computer program HEMIPHOTO [45] to analyze light levels in the hemispherical photographs; values were calculated as the relative photosynthetic photon flux density compared with that under conditions of full sun.

\section{RESULTS}

Both the mean DBH and the basal area did not differ significantly among the forest types (Tab. I). Planted L. kaempferi were significantly less dominant in OLD plots than in MID plots. The OLD plots were mixed forest composed of planted L. kaempferi and naturally regenerated deciduous broad-leaved species (e.g., Cornus controversa, Carpinus cordata, and Prunus maximowiczii). The relative photosynthetic photon flux density was significantly lower in OLD plots than in the other two types of forest.

The pattern of differences in species diversity and richness among the forest types is shown in Table II. Fewer species were found in SEC than in OLD, whereas MID and OLD contained statistically similar numbers of species. A total of 237 species were found in all plots: 163 in MID, 163 in OLD, and 109 in SEC plots (Fig. 2). The percentage of all species found in the study area that were unique to, or biased toward, a forest type was $37.4 \%$ in MID, $47.2 \%$ in OLD, and $24.8 \%$ in SEC plots. The species composition of each forest type was notably different (Figs. 3 and 4). Species composition in SEC plots differed significantly from those in MID and OLD plots; tall-tree species were significantly less common in plantations than in abandoned coppice forests (Fig. 3), particularly among species that were unique to, or biased toward, a forest type. To clarify the decline of tall-tree species in plantations compared with abandoned coppice forests, we focused on seed-dispersal types among the tall-tree species that were unique to, or biased toward, one type of forest (Fig. 4). Tall-tree species in SEC plots tended to use animals for seed dispersal. Although MID and OLD plots contained equal numbers of tall-tree species, the species had quite different seed-dispersal strategies. None of 
Table II. Species diversity index $\left(H^{\prime}\right)$, equitability $\left(J^{\prime}\right)$, and the number of species per unit area of each of the three forest types. Differences in these parameters among types were analyzed using the Kruskal-Wallis test, and the Mann-Whitney $U$ test with adjusted Bonferroni multiple comparisons was performed for each pair of types. Different letters indicate significant differences by adjusted Bonferroni multiple comparisons among forest types at $P<0.017$.

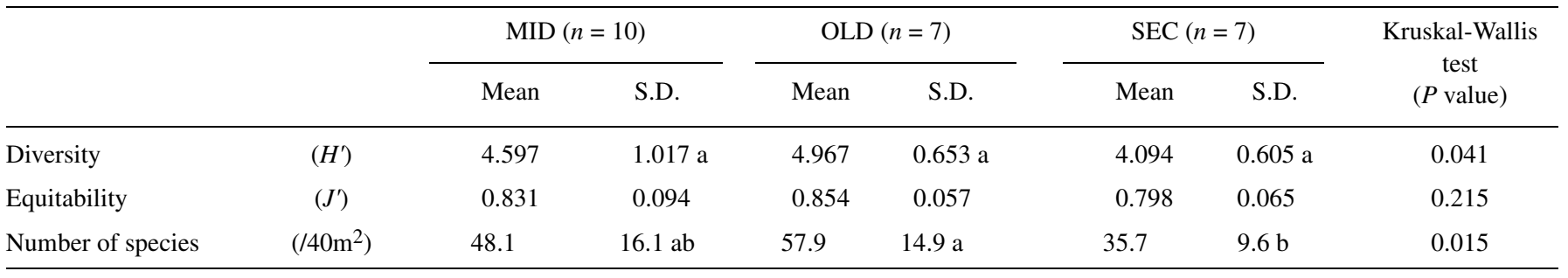

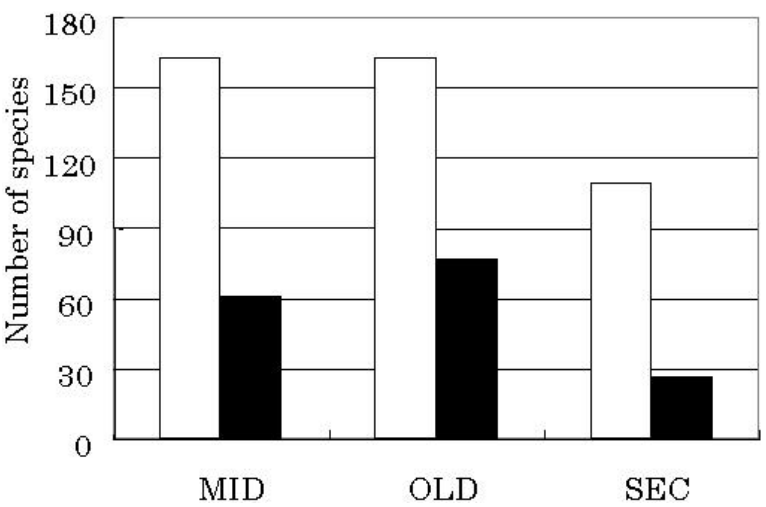

Figure 2. Total number of species recorded $(\square)$ and number of species unique to, or biased toward, a forest type (ם) for each forest type.

the tall-tree species in MID plots had animal-dispersed seeds, whereas OLD plots were comprised of species similar to those found in SEC plots, with animal-dispersed seeds.

\section{DISCUSSION}

The results of research comparing plant species diversity and richness among plantations and other types of forest are varied (e.g., $[6,11,31,40])$. In this study, species richness was significantly higher in long-rotation plantations than in abandoned coppice forest, although the data for the long-rotation plantations did not differ significantly from those for the standardrotation plantations (Tab. II). Whereas the plantations were managed for timber production after planting (i.e., via weeding, salvage cutting, and thinning), the abandoned coppice forest seemed not to have been managed since last clear-cut for firewood about 50 years ago. These differences in intensity and frequency of management (i.e., human disturbance) seem to have allowed many species to colonize the plantations rather than the abandoned coppice forest [2,31].

Differences in species type between standard- and long-rotation plantations were relatively small, but the differences between plantations and abandoned coppice forests were considerable (Figs. 2 and 3). The percentage of all species that were unique to, or biased toward, a particular forest type was higher for plantation species than for species in abandoned coppice forest; the plantations consisted mainly of species that did not

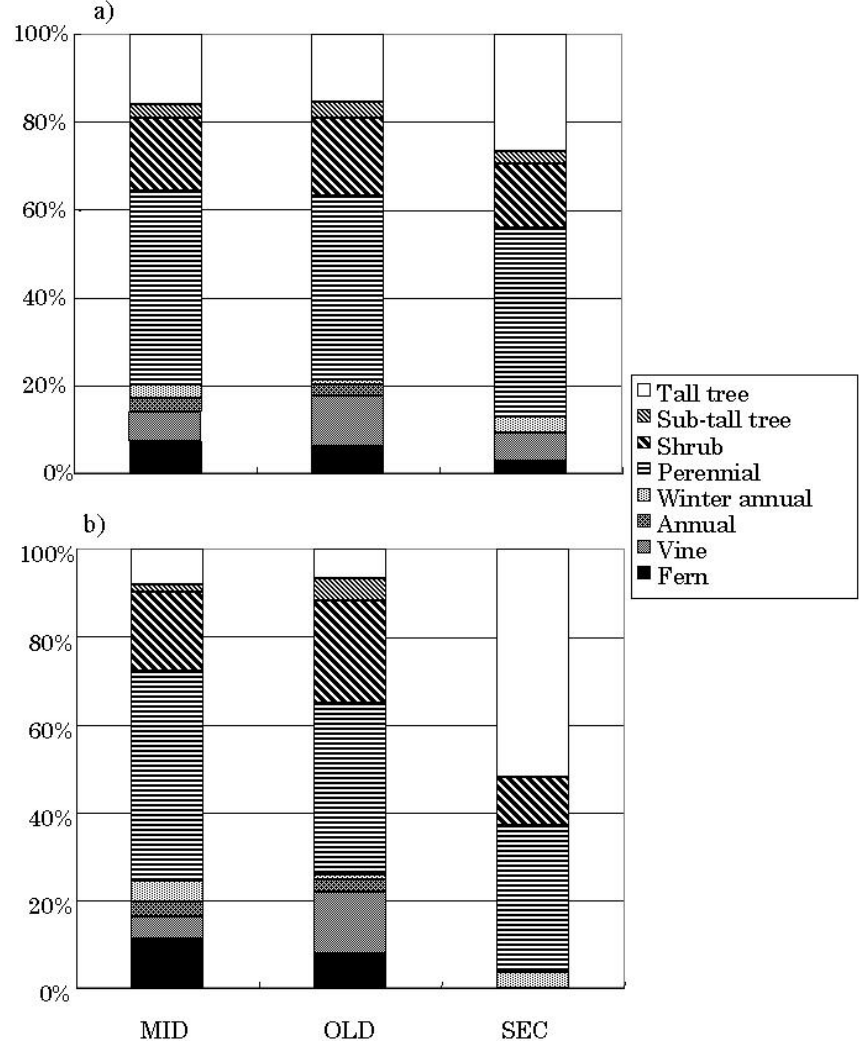

Figure 3. Life forms of species occurring in each forest type: (a) all recorded species and (b) species unique to, or biased toward, a forest type.

occur in the abandoned coppice forests (Fig. 2). Michelsen et al. [28] showed that most herbs in plantations were weeds or invasive species from wooded grasslands. Wallace et al. [48] also showed that cosmopolitan species were relatively resilient to the effect of plantations. As shown in Figure 3, the species that were unique to, or biased toward, a forest type differed between plantations and abandoned coppice forests; the plantations contained fewer tall-tree species. Plantation management studies have shown that shrub species are more resistant and recover more easily than tall-tree species [44]. Thomas et al. [46] also showed that tree species (seedlings and saplings) in a Pseudotsuga menziesii plantation in Washington, USA, 


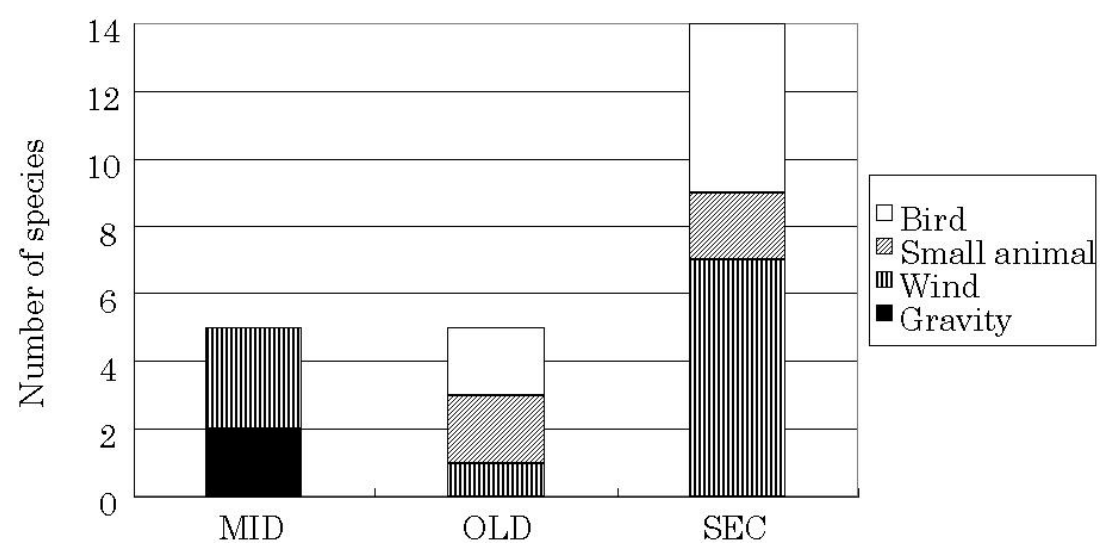

Figure 4. Tall-tree species seed dispersal types for species that were unique to, or biased toward, a forest type.

responded negatively to thinning. The different results in this study are probably due to different management strategies [31], and suggest that some tall-tree species are not favored by plantation management $[13,44]$.

Although species diversity, richness, and type did not differ between standard- and long-rotation plantations, the seed-dispersal type of tall-tree species did (Figs. 3 and 4). Keenan et al. [18] showed that the percentage of woody species with seeds dispersed by mammals and birds increased with age in a Pinus caribaea plantation in Australia. The tall-tree species in the long-rotation plantations included trees with animal-dispersed seeds ( $F$. japonica, $Q$. serrata, Kalopanax pictus, and Cornus controversa). The seed-dispersal type of the tall-tree species in the long-rotation plantations differed from those in the standard-rotation plantations and was similar to those in the abandoned coppice forest (Fig. 4). These results suggest that longrotation plantations might provide better conditions for the colonization of species with seeds that are dispersed by animals. Plantation management techniques, such as thinning, effectively set back the plant community to an early successional stage [29, 44]. The period since last management differed between the two types of plantation (5-10 years in the standard rotation plantations versus more than 30 years for the long rotation plantations). Some species with bird-dispersed seeds (e.g., Prunus maximowiczii and Cornus controversa) attain reproductive age in long-rotation but not in standard-rotation plantations (Nagaike \& Hayashi, unpublished data). Keenan et al. [18] pointed out that as plantations age, tree species that bear fruit that is attractive to frugivores have a chance to reproduce and, in turn, attract frugivorous birds [1, 49]. Wunderle [49] demonstrated the importance of traits relevant to attaining seed dispersers, including perch availability, structural complexity of vegetation, and the presence of food resources, especially fruit, as an attractant. The longer the period after last management, the more significant the role of this period may be for the growth, reproduction, and seed fall of naturally regenerated tall-tree species with animal-dispersed seeds. Long-rotation plantations could help restore not only plants but also their interactions with bird and mammal seed dispersers.

In conclusion, the species diversity and richness of longrotation plantations that had been unmanaged for 30 years were not significantly more diverse than those of standard-rotation plantations. Species composition in the standard-rotation plantations differed greatly from that in the long-rotation plantations and abandoned coppice forest, especially in terms of talltree species with animal-dispersed seeds. Therefore, extending the rotation period in standard-rotation plantations might restore plant species diversity and their ecological function.

Acknowledgments: We would like to thank Philippe Balandier of Cemagref de Clermont-Ferrand, France, for linguistic advice in French abstract and Midori Abe, Nana Ishiguro, and Nobumasa Arai of Niigata University, Japan, for their help in field data collection. We would also like to thank the members of the Yamanashi Forest Research Institute and the Prefectural Forest Division of Yamanashi Prefecture for their kind encouragement. This research was part of the Forest Ecosystem Monitoring Project of Yamanashi Prefecture and the "Sustainability and Biodiversity Assessment of Forest Utilization Options" Research Project of the Research Institute for Humanity and Nature, Japan and was partly supported by a Japan Society for the Promotion of Science (No. 16780121).

\section{REFERENCES}

[1] Alcántara J.M., Rey P.J., Velera F., Sánchez-Lafuente A.M., Factors shaping the seedfall pattern of a bird-dispersed plant, Ecology 81 (2000) 1937-1950.

[2] Bhuju D.R., Ohsawa M., Species dynamics and colonization patterns in an abandoned forest in an urban landscape, Ecol. Res. 14 (1999) 139-153.

[3] Bhuju D.R., Ohsawa M., Patch implications in the maintenance of species richness in an isolated forest site, Biol. Cons. 98 (2001) 117 125.

[4] Bossuyt B., Hermy M., Restoration of the understorey layer of recent forest bordering ancient forest, Appl. Veg. Sci. 3 (2000) 43-50.

[5] Dibble A.C., Brissette J.C., Hunter M.L. Jr., Putting community data to work: some understory plants indicate red spruce regeneration habitat, For. Ecol. Manage. 115 (1999) 275-291.

[6] Fahy O., Gormally M., A comparison of plant and carabid beetle communities in an Irish oak woodland with a nearby conifer plantation and clearfelled site, For. Ecol. Manage. 110 (1998) 263-273.

[7] Ferris R., Peace A.J., Humphrey J.W., Broone A.C., Relationships between vegetation, site type and stand structure in coniferous plantations in Britain, For. Ecol. Manage. 136 (2000) 35-51. 
[8] Fukamachi K., Iida S., Nakashizuka T., Landscape patterns and plant species diversity of forest reserves in the Kanto region, Japan, Vegetatio 124 (1996) 107-114.

[9] Gilliam F.S., Effects of harvesting on herbaceous layer diversity of a central Appalachian hardwood forest in West Virginia, USA, For. Ecol. Manage. 155 (2002) 33-43.

[10] Gilliam F.S., Turrill N.L., Adams M.B., Herbaceous-layer and overstory species in clear-cut and mature central Appalachian hardwood forests, Ecol. Appl. 5 (1995) 947-955.

[11] Hansson L., Interactions by vascular plants and birds between isolated ancient oak-hazel woods and a matrix of conifer plantations, Biol. Cons. 95 (2000) 191-196.

[12] Hartley M.J., Rationale and methods for conserving biodiversity in plantation forests, For. Ecol. Manage. 155 (2002) 81-95.

[13] Hasegawa M., The effects of weeding and improvement cuttings on the establishment of hardwoods in an unsuccessful Cryptomeria japonica plantation, J. Jpn. For. Soc. 73 (1991) 375-379 (in Japanese).

[14] Humphrey J.W., Newton A.C., Peace A.J., Hilden E., The importance of conifer plantations in northern Britain as a habitat for native fungi, Biol. Cons. 96 (2000) 241-252.

[15] Hunter M.L. Jr. (Ed.) Maintaining biodiversity in forest ecosystems, Cambridge University press, Cambridge, 1999.

[16] Iida S., Nakashizuka T., Forest fragmentation and its effect on species diversity in sub-urban coppice forests in Japan, For. Ecol. Manage. 73 (1995) 197-210.

[17] Jenkins M.A., Parker G.R., The response of herbaceous-layer vegetation to anthropogenic disturbance in intermittent stream bottomland forests of southern Indiana, USA, Plant Ecol. 151 (2000) 223-237.

[18] Keenan R., Lamb D., Woldring O., Irvine T., Jensen R., Restoration of plant biodiversity beneath tropical tree plantations in Northern Australia, For. Ecol. Manage. 99 (1997) 117-131.

[19] Kerr G., The use of silvicultural systems to enhance the biological diversity of plantation forests in Britain, Forestry, 72 (1999) 191-205.

[20] Kitamura S., Murata G., Colored illustrations of herbaceous plants of Japan (Choripetalae), Hoikusya, Osaka, 1980 (in Japanese).

[21] Kitamura S., Murata G., Koyama T., Colored illustrations of herbaceous plants of Japan (Monocotyledoneae), Hoikusya, Osaka, 1974 (in Japanese).

[22] Kitamura S., Murata G., Hori M., Colored illustrations of herbaceous plants of Japan (Sympetalae), Hoikusya, Osaka, 1978 (in Japanese)

[23] Kitamura S., Okamoto S., Colored illustrations of trees and shrubs of Japan, Hoikusya, Osaka, 1959 (in Japanese).

[24] Lindenmayer D.B., Future directions for biodiversity conservation in managed forests: indicator species, impact studies and monitoring programs, For. Ecol. Manage. 115 (1999) 277-287.

[25] Lindgren P.M.F., Sullivan T.P., Influence of alternative vegetation management treatments on conifer plantation attributes: abundance, species diversity, and structural diversity, For. Ecol. Manage. 142 (2001) 163-182.

[26] Marby C., Ackerly D., Gerhardt F., Landscape and species-level distribution of morphological and life history in a temperate woodland flora, J. Veg. Sci. 11 (2000) 213-224.

[27] Mason W.L., Quine C.P., Silvicultural possibilities for increasing structural diversity in British spruce forests: the case of Kielder Forest, For. Ecol. Manage. 79 (1995) 13-28.

[28] Michelsen A., Lisanework N., Friis I., Holst N., Comparisons of understorey vegetation and soil fertility in plantations and adjacent natural forests in the Ethiopian highlands, J. Appl. Ecol. 33 (1996) 627-642.
[29] Moore S.E., Allen E.L., Plantation forestry, in: Hunter M.L. Jr (Ed.), Maintaining biodiversity in forest ecosystems, Cambridge University Press, Cambridge, 1999, pp. 400-433.

[30] Nagaike T., A review of ecological studies on plant species diversity in plantation ecosystems, J. Jpn. For. Soc. 82 (2000) 407-416 (in Japanese with English summary).

[31] Nagaike T., Differences in plant species diversity between conifer (Larix kaempferi) plantations and broad-leaved (Quercus crispula) secondary forests in central Japan, For. Ecol. Manage. 168 (2002) $111-123$.

[32] Nagaike T., Kamitani T., Nakashizuka T., The effect of shelterwood logging on the diversity of plant species in a beech (Fagus crenata) forest in Japan, For. Ecol. Manage. 118 (1999) 161-171.

[33] Nagaike T., Hayashi A., Abe M., Arai N., Differences in plant species diversity in Larix kaempferi plantations of different ages in central Japan, For. Ecol. Manage. 183 (2003) 177-193.

[34] Numata M. (Ed.) The ecological encyclopedia of wild plants in Japan, Zenkoku Noson Kyoiku Kyokai, Tokyo, 1990.

[35] Peltzer D.A., Bast M.L., Wilson S.D., Gerry A.K., Plant diversity and tree responses following contrasting disturbances in boreal forest, For. Ecol. Manage. 127 (2000) 191-203.

[36] Peterken G.F., Aushermar D., Buchenan M., Forman R.T.T., Oldgrowth conservation within Upland conifer plantation, Forestry 65 (1992) 127-144.

[37] Peterson E.B., McCune B., Diversity and succession of epiphytic macrolichen communities in low-elevation managed conifer forests in Western Oregon, J. Veg. Sci. 12 (2001) 511-524.

[38] Pielou E.C., An introduction to mathematical ecology, Wiley-Interscience, New York, 1969

[39] Pinard M.A., Putz F.E., Rumíz D., Guzmán R., Jardim A., Ecological characterization of tree species for guiding forest management decisions in seasonally dry forests in Lomerio, Bolivia, For. Ecol. Manage. 113 (1999) 201-213.

[40] Qian H., Klinka K., Sivak B., Diversity of the understory vascular vegetation in 40 year-old and old-growth forest stands on Vancouver Island, British Columbia, J. Veg. Sci. 8 (1997) 773-780.

[41] Ratcliffe P.R., Peterken G.F., The potential for biodiversity in British upland spruce forests, For. Ecol. Manage. 79 (1995) 153-160.

[42] Roberts M.R., Zhu L., Early response of the herbaceous layer to harvesting in a mixed coniferous-deciduous forest in New Brunswick, Canada, For. Ecol. Manage. 155 (2002) 17-31.

[43] Semenova G.V., van der Maarel E., Plant functional type - a strategic perspective, J. Veg. Sci. 11 (2000) 917-922.

[44] Swindel B.F., Conde L.F., Smith J.E., Successional changes in Pinus elliottii plantations following two treatments, Can. J. For. Res. 16 (1986) 630-636.

[45] Ter Steege H., HEMIPHOTO, a programme to analyze vegetation indices, light quality from hemispherical photographs, The Tropebos Foundation, Wageningen, 1993.

[46] Thomas S.C., Halpern C.B., Falk D.A., Liguori D.A., Austin K.A., Plant diversity in managed forests: understory responses to thinning and fertilization, Ecol. Appl. 9 (1999) 864-879.

[47] Tracy B.F., Sanderson M.A., Patterns of plant species richness in pasture lands of the northeast United States, Plant Ecol. 149 (2000) $169-180$.

[48] Wallace H.L., Good J.E.G., Willams G., The effect of afforestation on upland plant communities: an application of the British Nationa Vegetation Classification, J. Appl. Ecol. 29 (1992) 180-194.

[49] Wunderle J.M. Jr., The role of animal seed dispersal in accelerating native forest regeneration on degraded tropical lands, For. Ecol. Manage. 99 (1997) 223-235. 